\title{
MUJER Y PODER EN EL REINO NAZARÍ DE GRANADA: FĀTIMA BINT AL-AHMAR, LA PERLA CENTRAL DEL COLLAR DE LA DINASTÍA (SIGLO XIV) ${ }^{1}$
}

\author{
WOMEN AND POWER IN THE NASRID KINGDOM OF GRANADA: \\ FĀTIMA BINT AL-AHMAR, THE CENTRAL JEWEL \\ OF THE NECKLACE OF THE DYNASTY (14th CENTURY)
}

\author{
BÁRBARA BOLOIX GALLARDO \\ Universidad de Granada
}

\begin{abstract}
Resumen: En la historia del reino nazarí de Granada, hubo mujeres que traspasaron el umbral del harén para ejercer importantes papeles en distintos ámbitos de la corte. Tal fue, en concreto, el caso de la sultana Fātima bint al-Ahmar (m. 749/1349), hija del emir Muhammad II, quien puede ser considerada la primera fémina conocida de esta estirpe en participar en los asuntos políticos del reino. Dada la gran influencia que esta mujer llegó a ejercer en el ámbito político, el presente artículo estará dedicado a la reconstrucción de su vida y de su personalidad, en función de la información suministrada por las fuentes árabes conservadas. Asimismo, se analizará de manera profunda su actividad política durante los complejos reinados de sus dos hermanos, Muhammad III y Nașr, de su primogénito Ismā īl I, y de sus dos nietos, Muhammad IV y Yūsuf I, durante los cuales la labor de Fātima resultó decisiva en los designios del reino de Granada.
\end{abstract}

Palabras Clave: mujeres; política; reino nazarí de Granada; Fāṭima bint al-Aḥmar; siglo XIV.

\begin{abstract}
Within the history of the Nasrid kingdom of Granada, a number of women tresspassed the threshold of their harem to play important roles in different aspects of the court. This was specifically the case of the sultana Fātima bint al-Ahmar (d. 749/1349), the daughter of emir Muhammad II, who can be considered the first lady of this lineage to participate in the political affairs of the kingdom. Due to the great influence that this woman exerted in the political arena, this article will be devoted to reconstructing both her life and her personality, according to the information provided by the preserved Arabic sources. Her political activities, developed throughout the complex rules of her two brothers, Muhammad III y Naș, her first-born son Ismā $\overline{1} l \mathrm{I}$, and her two grandsons Muhammad IV y Yūsuf I, will be also analyzed in depth because of their importance for the kingdom's history.
\end{abstract}

Keywords: women; politics; Nasrid kingdom of Granada; Fāțima bint alAhmar; 14th Century.

\footnotetext{
${ }^{1}$ Agradezco a los editores de este volumen, los Dres. Ana Echevarría Arsuaga y Nikolas Jaspert, el haber contado con mi colaboración en el mismo. Igualmente, expreso mi agradecimiento a los revisores externos del presente artículo que, con sus consejos y sugerencias, han contribuido al enriquecimiento y a la mejora de su contenido.
} 


\section{SUMARIO}

1. Introducción: mujer y poder en el Islam medieval, unas reflexiones.- 2. Fātima bint al-Ahmar: un antes y un después en el curso de la dinastía.- 3. La "segunda rama" reinante nazarí: ¿una dinastía ismā ilí o fātimí?.- 4. Actividad política de Fāṭima en tiempos de Muhammad IV y Yūsuf I.- 5. Conclusión.- 6. Bibliografía citada.

\section{INTRODUCCIÓN: MUJER Y PODER EN EL ISLAM MEDIEVAL, UNAS REFLEXIONES}

Desde siempre, y como sucede en el caso de la gran mayoría de las dinastías islámicas medievales, hemos conocido la historia del reino nazarí de Granada a través de los gobiernos engarzados de sus sultanes como principal hilo conductor. Éste ha sido, pues, el único hilo que nos ha conducido por los acontecimientos de toda índole -políticos, diplomáticos, económicos, sociales, científicos, religiosos, intelectuales, etc.- acaecidos a lo largo de la trayectoria vital de este emirato, desde el propio siglo XIII, en que fue fundado, hasta el XV, en que acaecieron su ocaso y final. El carácter eminentemente masculino de la historiografía árabe-islámica medieval ha sido, sin duda, el principal factor determinante de la visión, y versión, varonil que hoy tenemos de la historia, la cual ha sido escrita por y para hombres, quedando consecuentemente las mujeres relegadas a un segundo plano.

Sin embargo, la reconstrucción de la trayectoria de una dinastía no puede, ni debe, considerarse completa contando tan sólo con la versión masculina de la misma. Así lo reconoció la historiadora francesa Michelle Perrot al afirmar que una historia sin las mujeres parece imposible. Sin embargo, no siempre existió ${ }^{2}$. El que éstas tuvieron y ejercieron poder en la Edad Media es un hecho universalmente reconocido y aceptado por parte de quienes se dedican al estudio de la influencia femenina en las esferas políticas, a pesar del esfuerzo de las crónicas por condenar esta realidad. Curiosos datos, a veces muy camuflados en las fuentes, así lo demuestran, evidenciando que las mujeres de un linaje no fueron meros objetos pasivos del devenir histórico, sino, más bien al contrario, auténticos sujetos activos de éste. Igualmente los textos demuestran que las féminas llegaron a tener, en bastantes ocasiones, tanta implicación en los acontecimientos políticos como la propia figura del varón, a pesar de que la ordenación político-religiosa islámica señale la masculinidad o $\underline{d} u k \bar{u} r i y y a$ como condición sine qua non para ser califa. Este requisito es, asimismo, recalcado en el plano lingüístico, como demuestra la entrada que el acreditado

\footnotetext{
2 Perrot 2009, p. 6.
} 
diccionario clásico Lisān al- Arab dedica al término árabe "califa", del que argumenta que, a pesar de su terminación propia del femenino árabe, sólo es posible en género masculino (al-jalīfatu la yakūnu illà li-l-dakr $)^{3}$. Todo esto explica que nunca recayó sobre una mujer el título de califa o de imán en el sentido corriente de estos términos, aunque sí permitió la lengua árabe la existencia, al menos lingüística, de "sultanas" (sulțānāt) y de "reinas" (malikāt $)^{4}$.

El fenómeno del ejercicio del poder por parte de mujeres se dio de manera bastante clara en el Oriente islámico, el Magreb y al-Andalus medievales, así como en el área cristiana de la península Ibérica, lugares donde algunas de ellas fueron auténticas "hacedoras" (makers) de la historia, del arte y de la arquitectura, como recientes trabajos se han encargado de demostrar ${ }^{5}$. En el caso del contexto musulmán, existen numerosos ejemplos que así lo confirman. Remitiéndonos a Oriente, consta que hubo mujeres poderosas en el seno de la dinastía omeya de Damasco, a pesar de que los diccionarios biográficos les dediquen un porcentaje muchísimo menor que el de consagran a los hombres; entre estas féminas reales destacaron 'Ātiqa, hija del califa Yazīd I (60-63/680-683), o Hind, hermana de 'Utba y madre de Mu'āwiya I (4160/661-680), quien además descendía de los Banū Umayya por parte de ma$\mathrm{dre}^{6}$. Del mismo modo sucedió con las grandes féminas de la dinastía 'abbāsí, entre las que despuntó al-Jayzurān (m. 173/789), concubina yemení del califa al-Mahdī (158-169/775-785) y madre tanto de al-Hadī (169-170/785-786) como del célebre Hārūn al-Rašīd (170-193/786-809), una mujer cuyo modus operandi guarda mucha similitud con los procedimientos empleados por nuestra sultana Fāțima de la Alhambra ${ }^{7}$. En el Magreb, hubo también princesas que demostraron tener bastante influencia en los asuntos cortesanos, como 'Anbar (m. 737/1337), la madre del emir meriní Abū 1-Hasan (731-749/1331-1348), quien con frecuencia aconsejaba a su hijo en temas políticos ${ }^{8}$. En épocas de la historia de al-Andalus precedentes a la nazarí también hubo mujeres influyentes y determinantes en los destinos políticos de las dinastías en las que se enmarcaron, como la propia Șubh, favorita del califa omeya de Córdoba al-Ḥakam II (350-366/961-976), madre del desventurado Hišām II y presunta amante de Almanzor ${ }^{9}$.

3 Ibn Manẓūr 1956, vol. IX, p. 83; Mernissi 2008, p. 14.

${ }^{4}$ Ibidem,pp. 19, 26.

${ }^{5}$ Véanse, en este sentido, los recientes trabajos debidos a Martin 2005, 2006, 2012, entre otros títulos. Véase, asimismo, Boloix 2013.

${ }^{6}$ Abbott 1942,pp. 341-368; Roded 1999, pp. 77-78.

7 Abbott 1946; Roded 1999, pp. 85-86; Mernissi 2008, pp. 69-70, 77; Bosworth et al. 1978, s.v., Al-Khayzurān bint 'Ațā' al-Djurashiyya, vol. IV, p. 1164; Ziriklī 1969, vol. II, pp. 375-376.

${ }^{8}$ Boloix 2015, 2016.

9 Marín 1997, pp. 438-445; Bariani 1996, pp. 39-57; 2005, pp. 299-315. 
Descendiendo ya al detalle, comprobamos que tal fue también la realidad vivida en el reducido contexto del reino nazarí de Granada. Veinticuatro fueron, en total, los emires de esta dinastía, cortada, como era de esperar, según los patrones de los linajes islámicos medievales ${ }^{10}$. Sin embargo, la historia dinástica nazarí no fue precisamente fácil, ya que estuvo plasmada de conspiraciones, destronamientos, encarcelamientos y asesinatos políticos, afectando estos últimos, al menos trece sultanes que fueron eliminados en homicidios, combates y envenenamientos acaecidos en circunstancias más o menos turbias ${ }^{11}$. Ya fuese debido a la mortandad por guerra o en crímenes premeditados, lo cierto es que ambas coyunturas dejaron en numerosas ocasiones a las mujeres de la Alhambra desamparadas y obligadas a asumir papeles de gran responsabilidad. Dichas funciones las llevaron, a veces, a encabezar el cuidado de sus familias, la política del reino, el desarrollo de la diplomacia con los reinos cristianos peninsulares, la gestión del patrimonio real o la defensa de los derechos sucesorios de sus hijos, fuesen primogénitos o no, ante la posible usurpación del poder por parte de ramas familiares paralelas, entre otras responsabilidades ${ }^{12}$.

Como era de esperar, la participación de la mujer en la política nazarí no era contemplada en el plano teórico islámico, como pone de manifiesto el tratado compuesto por el célebre visir y secretario alhambreño Lisān al-Dīn Ibn al-Jațīb (m. 776/1374) bajo el título de Maqāma fì l-siyāsa (Sesión sobre la política) ${ }^{13}$. Entre los consejos planteados al sultán nazarí Muhammad V a lo largo de esta obra, figuraba la no conveniencia de encargar a sus mujeres (al-huram) asunto de gobierno pequeño ni grande, limitando el papel de estas últimas a ser mera tierra donde se plantan los hijos, los arrayanes del espíritu y el reposo del corazón ${ }^{14}$. Sin embargo, la práctica fue bien distinta, pues la acusada ausencia de varones o debilidad de éstos llevó a las mujeres de la dinastía nazarí a virilizarse socialmente, a asumir funciones masculinas, como apunta María Jesús Rubiera, ejerciendo, por lo tanto, en ocasiones de auténticos sujetos reinantes ${ }^{15}$. Esta realidad llevó a Maya Shatzmiller a considerar al sector femenino de la sociedad granadina como una república de mujeres en los últimos ocho años de historia nazarí, ante la abundancia de propiedades y

${ }^{10}$ Sobre la violencia desarrollada en al-Andalus en la época omeya cordobesa, véase Viguera 2011, pp. 81-107.

${ }^{11}$ Sobre los asesinatos políticos en el seno de la dinastía nazarí durante el siglo XIV, véase Vidal 2004, 2008.

${ }_{12}$ Salicrú 2011; Boloix 2013, pp. 40-41. Véase el cuadro genealógico incluido al final el presente artículo.

${ }^{13}$ Ibn al-Jațīb 2001, vol. IV, pp. 625-626; al-Maqqarī 1968, vol. VI, pp. 439-440.

${ }_{14}$ Boloix 2013, pp. 165-166.

15 Rubiera 1992, p. 67. 
bienes acumulados en manos femeninas, el alto número de matriarcados, así como la intensidad de sus actividades de compraventa ${ }^{16}$.

El mayor exponente de este fenómeno dentro de la corte nazarí fue, sin duda, el caso de la célebre sultana Fātima, figura única a la que dedicaremos las siguientes páginas de este trabajo, en el que aportaremos nuevos datos sobre su intensa y activa influencia en la política interna del reino de Granada.

\section{FĀṬTMA BINT AL-AHMAR: UN ANTES Y UN DESPUÉS EN EL CURSO DE LA DINASTÍA}

Hace ya prácticamente dos décadas que la desaparecida investigadora María Jesús Rubiera Mata rescataba del olvido, en un conciso pero revelador artículo, la memoria de una de las mujeres más influyentes de toda la dinastía nazarí: Fāṭima bint al-Aḥmar (m. 749/1349) ${ }^{17}$. Aunque este excelente trabajo, y otros títulos debidos a la misma autora ${ }^{18}$, fuese el gran punto de partida del estudio de esta emblemática figura, son todavía numerosos los datos que se esconden en las fuentes y que aportan mucha más información acerca de esta sultana y de sus actividades políticas en la corte de la Alhambra. A pesar del esfuerzo realizado a este respecto por quien suscribe en la monografía titulada Las Sultanas de la Alhambra ${ }^{19}$, sigue siendo aún necesario dedicar un trabajo único y exclusivo al análisis de su figura, en base a nuevos textos y, sobre todo, a nuevas reflexiones.

Fāțima es, sin lugar a dudas, una de las sultanas nazaríes de las que más información se ha conservado en las fuentes, siendo éste el primer gran indicio de su trascendencia histórica. A pesar de ello, la única biografía "oficial" que poseemos de esta mujer es aquella que le dedicó, de manera indirecta, el ya mencionado visir y secretario de la corte nazarí Lisān al-Dīn Ibn al-Jațīb (m. 776/1374), gran conocedor de las mujeres de la Alhambra, en su obra Al-Ihāạta fì ajbār Garnāța ${ }^{20}$. Es en esta fuente donde dicho cronista le dedica un nutritivo espacio a esta mujer, insertado en la semblanza del que fuera su hijo, el emir nazarí Ismā îl I (713-725/1314-1325), al referir quién fue su madre (uтти-hu).

\footnotetext{
${ }_{16}$ Shatzmiller 2007, p. 72. Véanse asimismo los trabajos reunidos por Calero 2006 y, en especial, Zomeño 2006.

17 Rubiera 1996.

${ }^{18}$ Véase también Rubiera 1989, pp. 75-76.

19 Boloix 2013.

${ }^{20}$ Ibn al-Jațīb 2001, vol. I, pp. 378-379. Véase también Boloix 2014, pp. 384-403.
} 
El primer detalle que llama la atención de Fāṭima es su propio nombre. Aunque se trata una nomenclatura muy habitual en la cultura islámica, apenas había sido portada anteriormente en el seno de la familia nazarí. Es cierto que la onomástica femenina de esta estirpe se inspiró en los primeros tiempos del Islam ${ }^{21}$; las fuentes disponibles muestran, de hecho, que la primera fémina que recibió esta denominación fue, precisamente, la "madre" de este linaje, Fāṭima bint Abī l-Ḥasan b. Ašqīlūla, progenitora del primer emir nazarí, Muhammad I (629-671/1232-1273) ${ }^{22}$. Tras ella, éste fue el nombre elegido para una de las hijas que dicho sultán tuvo con su prima paterna y primera esposa legítima, ' $\bar{A}$ 'iša, sin que se repitiese hasta llegar a nuestra protagonista $^{23}$. Cabe señalar que Fāțima no recibió al nacer el nombre de su abuela paterna, la recién mencionada ' $\bar{A}$ 'iša, como habría sido lo habitual según los cánones onomásticos tradicionales de la sociedad islámica. Al parecer, su nombre se remontaba a su bisabuela y, con ello, a una generación anterior a lo acostumbrado.

Lo que sí resulta muy significativo es que Fāṭima sí institucionalizase su nombre dentro de la familia nazarí, tal vez como consecuencia de la gran impronta que esta mujer dejó en la trayectoria y en la memoria de la dinastía en los años y siglos venideros. De hecho, así denominó su primogénito, Ismā̄ìl I, a una de las hijas que tuvo con su esclava 'Alwa, a la que otorgó el nombre de su ilustre abuela; de igual manera lo haría su nieto, el emir Yūsuf I (733-755/1333-1354), con una de sus múltiples descendientes ${ }^{24}$. Ya en el siglo XV, hallamos a dos mujeres nazaríes más documentadas bajo esta misma denominación: en concreto, una nieta del sultán Muhammad V (755-760/1354-1359; 763-793/1362-1391), hija de su vástago Nașr, y una de las dos hijas que engendrara Muḥammad IX el Zurdo (1419-1427; 1430-1431; 1432-1445; 851-857/1447-1453) con su esposa Umm al-Fath. Este fenómeno tuvo también su reflejo en la propia sociedad granadina, en la que también caló dicha moda onomástica ${ }^{25}$.

Pasando ya al ámbito de su vida, ninguna fuente menciona la fecha de nacimiento de la sultana Fāțima, aunque deducimos que pudo venir al mundo antes del año 659 (1260-1261), data calculada en función de la de su óbito,

${ }^{21}$ Arié 1990 p. 368.

22 Sobre la madre del sultán Muhammad I, véase Boloix 2006, pp. 134, 136-137, 145; 2013 , pp. 48-49; Boloix en prensa.

${ }^{23}$ Al-Bunnāhī 1863, p. 117. Véase el árbol genealógico nazarí ofrecido en Salicrú 1998, pp. 496-497 y recogido luego por Vidal 2000, pp. 244-245. Véase también el árbol genealógico de toda la familia nazarí en el que, por primera vez, son incluidas todas las mujeres nazaríes de los siglos XIII-XV documentadas en Boloix 2013, pp. 280-281; 2006, pp. 134-137 y 140.

${ }^{24}$ Al-Bunnāhī 1863, p. 132; Boloix 2013, pp. 70, 74, 141, 280-281.

${ }_{25}$ Sobre las implicaciones de este nombre en la historia del Islam y su repetición en el seno de los Banū Naṣr, véase Boloix 2013, pp. 139-143, 280-281. 
el año 749 (1349), pues consta que falleció con más de 90 años ${ }^{26}$. La Alhambra fue, pues, el marco privilegiado que vio tanto nacer como morir a esta mujer, constituyendo el principal escenario de su vida. En cuanto a sus progenitores, Fāṭima era fruto de la unión entre el emir Muḥammad II (671-701/1273-1302) y su prima materna, Nuzha, de la que también nació Muḥammad III (701708/1302-1309), hermano natural de nuestra protagonista ${ }^{27}$. Cabe señalar que el segundo sultán nazarí tomaría años después una segunda mujer, la esclava de origen cristiano (amatu-hu al-rūmiyya al-aṣl) Šms al-Ḍuhà (Sol de la Mañana), con la que engendraría al resto de sus hijos: el futuro emir Nașr (708-713/1309-1314), Faraŷ, Mu'mina y Šams, hermanastros todos ellos de Fāṭima $^{28}$. Resulta interesante detenerse en las dobles nupcias contraídas por Muhammad II, pues explicarán más tarde las distintas relaciones que nuestra sultana establecería con unos y otros hermanos en distintos episodios de su vida, en función de la mayor o menor densidad de su vínculo de sangre con ellos.

La gran inclinación hacia la cultura de su padre, Muḥammad II (quien no por menos se ganó el apodo de al-faqīh, el alfaquî) debió de ejercer una gran influencia en las inquietudes intelectuales de esta mujer. Sabemos por Ibn al-Jațīb que este emir se caracterizó por tener buena letra, escribir bellos tawqíes ${ }^{29}$, distinguir a los sabios -tales como médicos, astrónomos, filósofos, escritores y poetas - y el componer versos y gran número de sales y donaires ingeniosos $^{30}$. De este amor por el saber también se beneficiaron sus otros hijos varones, Muḥammad III y Nașr, dedicados a la poesía y a la astronomía, respectivamente ${ }^{31}$. Fâțima, por su parte, se consagró al cultivo de la ciencia de los barnāmaŷ o repertorios bio-bibliográficos de maestros y ulemas, pudiendo haber integrado la nómina de mujeres sabias de al-Andalus ${ }^{32}$. Es por ello lógico pensar que esta mujer pudo recibir educación privada en la propia Alhambra, al igual que sus hermanos.

Sin embargo, el rasgo más notorio de la personalidad de Fāṭima fue su gran capacidad política, adquirida a lo largo de su vida por distintos frentes.

\footnotetext{
${ }^{26}$ Pues falleció en el año 749 (1349) a los noventa años de edad, según Ibn al-Jațīb 2001, vol. I, pp. 378-379.

${ }^{27}$ Al-Bunnāhī 1863, p. 119.

${ }^{28}$ Ibn al-Jațīb 2001, vol. I, p. 559.

${ }^{29}$ Según Ibn al-Jațīb trad. 2010, p. 141, nota 3, el tawq $\bar{l}^{*}$ "era la resolución dada a la instancia de un súbdito al soberano, escrita por detrás o al margen de la misma solicitud; esta acotación o apostilla era campo adecuado para que la ingeniosa concisión del califa, o del secretario que le sustituyese, celebrase en ella sus talentos".

${ }^{30}$ Ibn al-Jațīb 2001, vol. I, p. 557; Ibn al-Jațîb 1980, p. 50; trad. 2010, pp. 141-142.

${ }^{31}$ Ibn al-Jațīb 2001, vol. I, pp. 545-546; vol. III, p. 334; Ibn al-Jațīb 1980, pp. 61-62, 70; trad. 2010, pp. 156-158 y 169.

32 Ávila 1989; Viguera 1989; Rubiera 1996, p. 184; Marín 2006; Boloix 2013, pp. 60-61.
} 
No olvidemos que el propio Ibn al-Jațīb la definió como una nobilísima dama emparentada con los reyes [por los cuatro costados], pues no solamente era hija de Muhammad II, sino hermana de los también emires Muhammad III (701-708/1302-1309) y Nașr (708-713/1309-1314), ambos soberanos de gran ambición; una codicia que no encontró límites en el caso de Muhammad III, quien fue el responsable de la muerte repentina de su propio padre en el año 701 (1302), al que envenenó con un bizcocho $\left(k a^{i} k^{a n}\right)$ que le había enviado la noche anterior. Aunque Ibn al-Jațīb camufló esta versión de los hechos en la biografía de dicho sultán, sí la reveló abiertamente en la semblanza que dedicó al que fuera su médico de cámara (tabīb al-dār al-sulțāniyya), el abencerraje Abū Abd Allāh Muḥammad b. Rawab̄il al-Anșārī (m. 730/1329), más conocido como Ibn al-Sarrâŷy $\hat{}^{3}$. Para tapar su culpabilidad en el fratricidio, Muhammad III ordenaba erigir el cementerio real de la Rawḍa, dentro del recinto alhambreño, para dar sepultura a su padre; una necrópolis en la que, años más tarde, sería inhumada con gran boato Fātima pero no el hermanastro de ambos, Nașr, quien, por el contrario, fue enterrado en el cementerio real de la Sabīka, es decir, aquél que se extendía por la colina del mismo nombre sobre la que se asienta la Alhambra ${ }^{34}$.

No sabemos cómo pudo influir este crimen en la relación que Fāțima, que por aquel entonces debía contar con más de treinta años, tenía con su hermano uterino Muhammad III. Parece ser que el vínculo entre ambos siguió siendo estrecho, como demostraremos más adelante, tal vez porque estos desagradables acontecimientos la sorprendieran lejos, viviendo ya en Málaga. A esta ciudad se había trasladado Fātịma tras ser desposada por su padre, siendo núbil, con su tío paterno Abū Sa īd Faraŷ (m. 720/1320), quien era arráez de esta estratégica plaza. Confirma esta hipótesis el hecho de que el primer hijo de ambos, Ismā îl I, llegaba al mundo bastante después, en 677 (1279); es decir, veinticuatro años antes de producirse el asesinato de Muḥammad II $^{35}$. Más tarde nacería su otro vástago, Muḥammad, en una fecha que ignoramos. En la alcazaba malagueña debió de vivir esta mujer una vida tranquila dedicada al cuidado de sus hijos, pero sin estar al margen de los acontecimientos políticos de Granada.

Este matrimonio convirtió a Fāṭima en una importante pieza política. Y es que, aunque su marido nunca llegó a ser emir por pertenecer a una rama distinta de la legítima, sí constituía una pieza clave en el gobierno de Muhammad II, tanto como lo era Málaga en el dominio del Estrecho ${ }^{36}$. En

${ }^{33}$ Ibn al-Jațīb 2001, vol. III, pp. 161-162; Boloix 2007, p. 590.

${ }^{34}$ Ibn al-Jațīb 2001, vol. III, p. 341; 1980, p. 76, trad. 2010, p. 177.

${ }^{35}$ Ibn al-Jațīb 2001, vol. III, p. 341; 1980, p. 88, trad. 2010, p. 194.

${ }^{36}$ Rubiera 1996, p. 185. 
el espacio biográfico que le dedica, Ibn al-Jațīb nos ilustra a Abū Sa īd Faraŷ como un hombre fuerte personalidad, muy inteligente y justo, dotado de una voz potente y de una gran generosidad, y que no daba importancia a la fama ${ }^{37}$. Había sido, ante todo, un excelente consejero desde su juventud y un experto militar en la guerra naval, dedicándose incluso a construir grandes barcos ( $b i$ našă' al-marākib al-kibār) en Málaga, lo que le reportó abundantes ganancias y alabanzas ${ }^{38}$. De hecho, su actividad en las atarazanas malagueñas explica para María Jesús Rubiera el gran poder de la flota nasri en los años sucesi$v s^{39}$. Por esta razón el padre de Fāțima no sólo le concedió a su hija en matrimonio, sino que también le confió el gobierno de la importante plaza malagueña. Ello sucedía tras haber recuperado este enclave de manos rivales, pues los primeros arraéces que lo habían controlado, los Banū Ašqīlūla, habían cedido Málaga a los Meriníes, desgajando esta ciudad de la autoridad nazarí, lo que aumentó el temor de que, con esta maniobra, aquéllos acabaran extendiendo su soberanía por todo al-Andalus ${ }^{40}$. En Málaga gobernaría Abū Sa īd Faraŷ casi hasta su muerte con gran autoridad y lealtad, pues se nos presenta durante los años de su wilāya como un gran señor, al que los literatos dedican sus obras y rodeado de gran prestigio tanto civil como militar ${ }^{41}$.

Muhammad III confiaba plenamente en Abū Sa īd Faraŷ, como reconoce Ibn Jaldūn ${ }^{42}$, y tuvo la inteligencia de mantenerlo en sus funciones desde el inicio hasta el final de su reinado, a lo largo del cual aquél siguió ejerciendo de escudo contra el avance meriní en el reino de Granada y llegó a extender la autoridad nazarí por el Norte de África. Y es que el marido de Fāṭima fue el responsable de dirigir la arriesgada expedición militar que acabaría con la conquista nazarí de Ceuta en 705 (1306), contribuyendo a la proclamación de Muhammad III en esta plaza norteafricana.

Todos estos acontecimientos políticos llevan a deducir la existencia de una buena relación entre Fāṭima y su hermano carnal, el emir Muhammad III, considerando que este último mantuvo a Abū Sa īd Faraŷ, su marido, en las funciones militares durante su gobierno y que el arráez colaboró constantemente en las empresas del sultán nazarí. Esta actitud explica que ambos cónyuges se mantuvieran al lado de dicho soberano cuando, en el año 708 (1309), éste fue derrocado y obligado a abdicar por su medio hermano Nașr, quien además lo encarceló en Almuñécar; un momento en que se abre la caja

${ }^{37}$ Ibn al-Jațīb 2001, vol. IV, pp. 241-246.

38 Boloix 2007, pp. 542-543.

${ }^{39}$ Rubiera 1975, p. 128.

${ }^{40}$ Ibidem.

${ }^{41}$ Ibidem, p. 130.

${ }^{42}$ Ibn Jaldūn 1956, vol. IV, p. 159. 
de Pandora de todos los males ocultos del emirato nașr $\bar{t}^{43}$. A partir de esta importante fecha no sólo algunos enclaves nazaríes sufrirían duros asedios por parte de los castellanos, sino que también se perdió la plaza de Ceuta en el mismo año en que se producía la subida al poder de Nașr. Este último hecho supuso la vuelta de Abū Sa īd Faraŷ a Málaga, ciudad en la que continuaría residiendo la princesa Fātima ${ }^{44}$.

La actitud de apoyo de Abū Sa īd Faraŷ y, supuestamente también de Fāṭima, hacia Muḥammad III nada tuvo que ver con la oposición que ambos demostraron hacia el joven Nașr. Este antagonismo seguramente se acrecentó cuando el destronado emir, que ya estaba enfermo, apareció ahogado en una alberca un lunes 3 de $\breve{s} a w w \bar{a} l$ de 713 (21 de enero de 1314) a los 56 años $^{45}$; una edad seguramente parecida a la que debía de tener Fāțima en ese momento, pues, junto a Muḥammad III, era también hija del primer enlace de Muhammad II. Esta época oscura, en la que Abū Sa īd Faraŷ y Fāțima fueron seguramente apartados del poder, fue al parecer aprovechada por ambos para urdir una venganza que solucionara a la vez la cuestión familiar y la situación conflictiva del reino nazarí. Es por ello que, aprovechando el clima de descontento de un sector de la población granadina por la política interna desarrollada por Nașr, Abū Sa īd Faraŷ no decidió proclamarse él mismo emir, aunque habían intentado convencerlo de ello, sino enviar a su hijo Ismā î̀ I a Granada para que éste fuese nombrado. La sublevación contaba con los apoyos necesarios, entre los que figuraban el de meriníes y castellanos ${ }^{46}$. Un viraje en la historia de la dinastía nazarí digno de analizar, por la implicación directa que en él tuvo la madre del nuevo emir, Fāțima, y las múltiples consecuencias que trajo al desarrollo posterior de este linaje, como comprobaremos a continuación.

\section{LA "SEGUNDA RAMA" REINANTE NAZARÍ: ¿UNA DINASTÍA ISMĀ ILÍ O FĀṬIMÍ?}

Tras varios enfrentamientos bélicos, recuperación de importantes enclaves nazaríes y serias dificultades, un sábado 27 de šawwāl del año 713 (14 de febrero de 1314) Abū l-Walīd Ismā îl I conseguía por fin entrar en Granada. Ello sucedía a finales del mismo mes en el que había sido asesinado su tío Muhammad III, tomando la Alhambra dos días después con la consecuente huida del depuesto emir Nașr a Guadix, ciudad en la que nueve años más tarde

${ }^{43}$ Rubiera 1975, p. 130.

${ }^{44}$ Ibidem, p. 131.

${ }^{45}$ Sobre el asesinato de este emir nazarí, véase Vidal 2004, pp. 360-364.

${ }^{46}$ Vidal 2000, vol. VIII-3, p. 122. 
terminarían sus días ${ }^{47}$. Curiosamente, el sultán Nașr ni siquiera sería enterrado en la Rawda que había construido Muhammad III, al que había asesinado, como ya referimos anteriormente. Comenzaba una nueva etapa para el reino de Granada y un punto de inflexión para la dinastía nazarí, a partir del cual se desvanecería, curiosamente, la figura de Abū Sa īd Faraŷ a la vez que cobraba una mayor visibilidad la de la sultana Fātima.

Una vez Ismā îl I se hizo con el poder, los textos árabes dejan a Abū Sa īd Faraŷ situado en Málaga, iniciando un sospechoso silencio sobre la estela que seguiría su vida. Sin embargo, datos concretos llevaron a María Jesús Rubiera a suponer que ciertas negociaciones secretas iniciadas por este personaje con los Meriníes llevaron a su hijo, Ismāi îl I, a destituirlo de sus funciones y a encarcelarlo primeramente en la fortaleza de Cármata para ser, finalmente, confinado a la prisión real de Salobreña. Allí fallecería Abū Sa'îd Faraŷ el 14 de $\mathrm{rabĭ}^{\circ}$ I de 720 (24 de abril de 1320), siendo trasladado al ya mencionado cementerio de la Sabīka; a su funeral acudieron representantes de la aristocracia y gente distinguida, que mostraron una gran tristeza, mientras su hijo Ismā'îl I permanecía de pie ante a su sepultura ${ }^{48}$.

Todos estos acontecimientos revelan, entrelíneas, la fría relación que el nuevo emir llegó a mantener con su progenitor para conservar el poder, a pesar de que Ibn al-Jațīb afirme que se crió ocupado en las cosas propias de su condición, disfrutando del favor de su padre (ni mat abī-hi) ${ }^{49}$. Sin embargo, esta supuesta armonía familiar no le impidió apartar a Abū Sa īì Faraŷ del gobierno militar de Málaga, al que se había dedicado toda su vida, ni encerrarlo en prisión. Por el contrario, sí existen argumentos para calibrar la buena relación que Ismā̄îl I sí debió de mantener con su madre. Para empezar, resulta curioso que, en la biografía de este sultán, Ibn al-Jațīb le dedique un curioso espacio a Fāțima en detrimento del silencio que guarda respecto a su progenitor; y es que Ismā îl I era, precisamente, el preferido de su abuelo materno, Muhammad II, como Ibn al-Jațīb no duda en reconocer ${ }^{50}$. Es por ello que parece bastante clara la intervención de Fāṭima en la proclamación de su hijo, siendo seguramente determinante el apoyo que esta sultana también le rindió para que los asuntos clandestinos de su padre no enturbiasen su gobierno.

El nombramiento de Ismā īl I fue, sin duda, el único recurso posible para mantener la línea legítima reinante de la dinastía nazarí en el poder. Y es que, aunque siempre se ha afirmado que, a partir de este soberano, comienza el

\footnotetext{
${ }^{47}$ Ibn al-Jatịib 2001, vol. III, p. 341; Ibn al-Jațīb 1980, p. 76, trad. 2010, p. 177; Rubiera 1975, pp. 131-132; Vidal 2000, vol. VIII/3, p. 122; 2004, p. 387.

${ }^{48}$ Ibn al-Jatịb 2001, vol. IV, p. 244.

${ }^{49}$ Ibidem, vol. I, p. 377; Ibn al-Jațīb 1980, p. 78, trad. 2010, p. 182.

${ }^{50}$ Ibn al-Jațīb 2001, vol. I, p. 377; Ibn al-Jațīb 1980, p. 78, trad. 2010, p. 182.
} 
gobierno de la segunda rama de la dinastía, en realidad no debería haber motivos para interpretar que, con él, se produjo tal cambio; Ismā îl I era heredero directo de aquella línea dinástica inaugurada en el siglo XIII por Muhammad I, aunque no por parte de padre sino de madre. No olvidemos que Fāṭima sí era descendiente directa de Muḥammad I y de Muḥammad II, su progenitor, al igual que lo habían sido sus hermanos Muḥammad III y Nașr. El problema es que con estos dos soberanos la dinastía había llegado a un callejón sin salida, pues Muhammad III había fallecido sin dejar descendencia y Nașr, prisionero en Salobreña, tampoco contaba con sucesores; pero Fāṭima sí: su hijo Ismā īl. Es por ello que no hay que ver, pues, en Ismā îl I a un "usurpador" del poder ni tampoco una ruptura con respecto a la trayectoria sanguínea anterior, sino a un continuador de la misma, aunque dicha continuación se diera gracias a la sangre nazarí heredada de su madre.

Es aquí donde se produce un fenómeno muy curioso de transmisión del poder por línea femenina dentro del linaje de la Alhambra, sobre el que ya advirtió María Jesús Rubiera ${ }^{51}$. Nos referimos a la mayor fuerza que la sangre de algunas mujeres nazaríes tuvo sobre la de sus maridos tanto en la transmisión de la nobleza de su linaje como del derecho a reinar de sus hijos. Dentro de la dinastía de la Alhambra hubo significativos casos en los que se contradijo el principio islámico de tomar como esposas a mujeres pertenecientes a linajes socialmente más débiles que los masculinos, estableciéndose en consecuencia matrimonios desiguales. No olvidemos que la jurisprudencia islámica medieval establecía que el futuro marido debía tener una situación económica y social igual o superior a la de su mujer ( $\left.k a f \bar{a}^{\prime} a\right)$, pero nunca inferior, condición que los propios jueces debían verificar y que quedaba reflejada en la mayor o menor dote que el novio tenía que entregar a la novia ${ }^{52}$. Sin embargo, el árbol genealógico nazarí evidencia cómo algunas de sus mujeres fueron desposadas tanto con miembros de la propia estirpe como con candidatos de familias diferentes, casos en los que estas princesas eran consideradas socialmente superiores a sus parientes políticos, siendo su sangre primordial en la consolidación de la estirpe ${ }^{53}$.

La primera vez que se dio este insólito fenómeno del ascenso al poder por línea materna dentro de la dinastía nazarí fue, precisamente, con el emir Ismā î̀ I, quien pudo ascender al trono gracias a la sangre real nazarí de su madre, Fāṭima, pues su padre, Abū Sa īd Faraŷ, no podía transmitirle ninguna capacidad sucesoria por no pertenecer a la rama reinante legítima. Este

${ }^{51}$ Rubiera 1978, pp. 121-124.

${ }^{52}$ Zomeño 2000, p. 87; Boloix 2013, pp. 36-37.

${ }^{53}$ Ibidem, pp. 36-37, 65, 280-281. 
caso sentaría un precedente que determinaría otra situación, todavía más evidente, acaecida en el siglo XV: el del emir Yūsuf IV Ibn al-Mawl (835/1432), quien era hijo de una mujer nazarí -hija a su vez del sultán Muḥammad VI el Bermejo (761-763/1360-1362)- y de un miembro de los Banū l-Mawl de Córdoba. Como es obvio, Yūsuf IV reinó gracias a la sangre nazarí de su madre, pues su padre pertenecía a una familia completamente ajena a la real; una excusa aprovechada por los cristianos para justificar su apoyo a este emir ${ }^{54}$.

Otra cuestión que cabría calibrar, llegados a este punto, es la propia denominación que recibió la rama dinástica supuestamente inaugurada por Ismāî̀ I, la cual es referida en las fuentes árabes como al-dawla al-Ismä ìliyya o la dinastía de Ismã $\bar{\imath} l$, a pesar de que Fāțima había sido el verdadero origen de esta nueva línea sucesoria, a la que dotó de legitimidad y sangre real. La historia del Islam cuenta, lamentablemente, con muy pocos ejemplos de dinastías que hundieron sus raíces en epónimos femeninos. Sin duda, el caso más emblemático fue el de la célebre dinastía Fāṭimí de Egipto (siglos X-XII), un linaje que, por motivaciones religiosas, derivó su nombre de la hija del profeta Mahoma, Fāṭima al-Zahrā' (m. 632). Esta mujer fue oficialmente considerada por esta dinastía transmisora de la sucesión consanguínea, como lo fue, salvando las distancias de todo tipo, nuestra Fāțima nazarí, con la que se establecieron unas reglas matriarcales de transmisión del poder sin precedentes en la Alhambra ${ }^{55}$.

La sultana Fāțima debió de constituir un apoyo fundamental para su hijo Ismā îl I (713-725/1314-1325) durante su reinado, sobre todo desde que su padre fuese hecho prisionero y falleciese en el año 720 (1320). Así lo afirma María Jesús Rubiera, para quien Fāțima bint Abī Abd Allāh b. Nașr estaba tan dotada de grandes cualidades como su marido ${ }^{56}$. No sabemos si esta sultana madre acudió a la Alhambra para asistir, desde la sombra, al sepelio de Abū Sa īd Faraŷ; pero lo que sí parece lógico es que pudo trasladarse al palacio real nazarí a partir de este momento o, tal vez, que ya viviese allí desde antes. En la Alhambra pudo residir con la propia familia $(a h l)$-es decir, la mujer e hijosdel sultán Ismāî̀ I, pues consta que la esposa de este último lo acompañaba en su entrada en el palacio cuando se hizo con el poder, como revela el propio Ibn al-Jațīb: El sultán se refugió en la fortaleza de la Alhambra, entrando en ella con su familia (bi-ahli-hi), sus tesoros y la alta nobleza ${ }^{57}$. La presencia continua de Fātima en el reinado de su hijo se vislumbra en las menciones que Ibn al-Jațīb le dedica en distintos puntos de su obra como la madre de Ismä $\bar{\imath} l[\mathrm{I}]^{58}$.

${ }^{54}$ Sobre este asunto, véase Echevarría 2006, quien lo trata ampliamente en este estudio.

${ }^{55}$ Boloix 2013, pp. 65-66.

${ }^{56}$ Rubiera 1975, p. 128.

${ }^{57}$ Ibn al-Jațīb 2001, vol. I, p. 387; Ibn al-Jațīb 1980, p. 83, trad. 2010, p. 187.

${ }^{58}$ Ibn al-Jațīb 2001, vol. I, p. 559. 
Sin embargo, esta sultana también sería testigo de situaciones más amargas, como el asesinato de su vástago en 1325, cometido por el que fuera arráez de Algeciras y primo paterno del emir, Muhammad b. Ismā ìl, cuando aquél regresaba de una aceifa en Martos. Su deudo actuaba así en venganza por la represión a la que Ismāīi I le había sometido, así como por una fuerte reprimenda que el emir le había dispensado ante su capricho por una esclava cristiana que su primo Muhammad había capturado en Martos y que no le quiso ceder ${ }^{59}$. Este último, asistido por un grupo de parientes y adeptos suyos, asaltó al emir con una daga en su consejo privado, asestándole tres puñaladas, una de las cuales le cortó la arteria carótida. Ismāî̀ I fue inmediatamente conducido a uno de sus aposentos del palacio alhambreño donde, según detalla la Crónica de don Alfonso el Onceno ${ }^{60}$, se hallaba su madre, Fātịma: Et tornó [el alguacil] del Rey (...) et tomólo en los brazos, et esforzándose, levólo a un palacio do estaba su madre del Rey ${ }^{61}$. Aunque el emir logró resistir algo gracias que a que le fue aplicado un emplasto y a que su turbante le taponó la herida, falleció finalmente a los cuarenta y siete años ${ }^{62}$. Ello sucedía un lunes 26 de raŷab de 725 ( 8 de julio de 1325), siendo enterrado a los dos días en el cementerio de la Rawda alhambreña ${ }^{63}$.

Fāțima, que debía de contar con unos 66 años lunares, quedaba como responsable de la situación venidera: la proclamación de su nieto menor de edad, Muhammad IV, como heredero y primogénito de su asesinado padre. Y es que es posible que la madre de éste, la concubina cristiana 'Alwa, preferida de Ismā îl I, no llegara a tener mucho poder de decisión en el reinado de su propio hijo, aunque sea una simple conjetura ${ }^{64}$. Para empezar, era una cristiana manumitida y no una esposa legítima; además, aunque esta mujer sobrevivió a Ismā īl I, consta que este sultán la había repudiado en vida por un asunto, al parecer delictivo, al que la llevó su coquetería, tomando otras mujeres extranjeras como madres del resto de su prole, lo que seguramente mermaría la influencia de Alwa en la Alhambra ${ }^{65}$.

${ }^{59}$ Vidal 2004, p. 375.

${ }^{60}$ Crónica 1787, pp. 206-207, cap. 5.

${ }^{61}$ Apud Vidal 2004, p. 377, n. 74.

${ }^{62}$ Sobre el asesinato de este emir nazarí, véase Vidal 2004, pp. 370-381.

${ }^{63}$ Ibn al-Jațīb 2001, vol. I, pp. 392-393; Ibn al-Jațīb 1980, pp. 87-88, trad. 2010, p. 192.

${ }^{64}$ Boloix 2013, p. 72.

${ }^{65}$ Sobre las concubinas en al-Andalus, véase Puente 2007a, 2007b, 2013. 


\section{ACTIVIDAD POLÍTICA DE FĀṬIMA EN TIEMPOS DE MUHAMMAD IV Y YŨSUF I}

Al morir asesinado su hijo, el emir Ismā‘īl I, en el año 725 (1325), se intensificó la participación de Fātịma en los asuntos palaciegos nazaríes. Y es que su nieto Muhammad IV era proclamado emir con tan sólo 10 años de edad, el mismo 26 de raŷab de 725 (8 de julio de 1325), en que había fallecido asesinado su padre. La minoría de edad de aquél llevó a esta sultana a ejercer la tutela del mismo a medias con un preceptor, llamado Ridwān ${ }^{66}$. Sin embargo, el papel de Fāțima en la corte de la Alhambra durante esta época no se limitó tan sólo a los asuntos domésticos, sino que debió de tener un largo alcance, como lo demuestra cierto movimiento de fichas que ella misma realizó para proteger el reinado de Muhammad $\mathrm{IV}^{67}$. Fue, sin duda, éste el periodo de mayor actividad política de esta mujer, razón tal vez por la que Fāțima también pasó a la historiografía de Ibn al-Jațīb como la abuela del sultán, según se advertirá a continuación.

Sin duda el hecho más evidente de la participación de esta mujer en los asuntos cortesanos fue su intervención en el premeditado asesinato de Abū 'Abd Allāh Muḥammad Ibn al-Maḥrūq al-Aš arī (m. 729/1328), delegado (wakīl) de Ismāīi I que intentó establecer una dictadura personal aprovechando la minoría de edad de Muhammad IV $V^{68}$; de hecho, Ibn al-Jațīb lo define como qahramān (es decir, administrador o intendente) de la casa real nazarí (al-dār al-sulțāniyya) ${ }^{69}$. Fue en tiempos de este último sultán cuando este personaje mantuvo una gran rivalidad por el liderazgo político con el que era el šayj al-guzāa' (jefe de los combatientes de la fe) meriní en al-Andalus, Abū Sa īd 'Uțmān b. Abī l-'Ulà. Temiendo Ibn al-Mahrūq que éste pudiera hacerse con el reino nazarí, y ante el control que el meriní ejercía sobre el resto de los ministros, el visir resolvió buscar un enemigo que le hiciera frente, un miembro de los Banū Raḥhū, llamado Yahyyà b. 'Umar, que había sido deportado a Túnez por Abū Sa īd 'Uțmān y al que Ibn al-Mahrūq había designado šayj al-guzä' por su cuenta y riesgo. Esta maniobra fue, al parecer, el detonante por el que Ibn al-Mahrūq fue asesinado, pues tal nombramiento ponía en peligro la lealtad de las tropas meriníes en al-Andalus hacia el inexperto Muhammad IV ${ }^{70}$; una amenaza de la que fue consciente Fāțima, quien pronto tomó cartas en el asunto.

${ }^{66}$ Ibn al-Jațīb 2001, vol. I, pp. 532-533; 1980, p. 90, trad. 2010, p. 197.

${ }^{67}$ Rubiera 1996, p. 188.

${ }^{68}$ Biografiado por Ibn al-Jațîb 2001, vol. II, pp. 136-137.

${ }^{69}$ Ibidem, vol. I, p. 136; Martínez 1994, p. 218; Arié 1990, p. 214.

${ }^{70}$ Manzano 1992, pp. 349-351, 355. 
Los crímenes políticos perpetrados por mujeres eran, en realidad, un leit motiv mucho más frecuente en la historia del Islam de lo que puede pensarse. Y es que al igual que los hombres, las mujeres practicaron el asesinato político cuanto lo necesitaron, quizás con métodos más "suaves" que el uso de la espada, como la asfixia o el envenenamiento ${ }^{71}$. Distintas fuentes -nazaríes, magrebíes e incluso orientales- ofrecen versiones variadas de este asesinato, cuya veracidad mediremos en función de la mayor o menor cercanía del autor al escenario de los hechos. Comenzando por el cronista más próximo a la Alhambra, Ibn al-Jațīb, diremos que al menos dos de sus obras atribuyen la decisión de aniquilar a Ibn al-Mahrūq al propio Muḥammad IV, si bien en otros puntos de sus escritos este autor reconoce, explícitamente, la involucración de Fāțima en dicho crimen ${ }^{72}$. Así, en la reseña que dedica a Ibn al-Mahrūq en su célebre Ihạța, este cronista revela lo que acaeció al final de sus días:

Se puso nervioso, pero resolvió ejecutar su plan contra él, siendo asaltado por dos jóvenes esclavos, que se habían quedado con su protegido en la casa de la gran Señora, la abuela del sultán (dār al-ḥurra al-kabīra ŷaddat al-sulțān), a la que solía consultar sobre los asuntos [políticos] por considerarla un bastón para sus intereses. Sin embargo, ambos lo alcanzaron, lanzándose sobre él con los alfanjes. El [Ibn al-Mahrūq] se arrojó a la cisterna de la casa, mientras que ambos no cesaron de acuchillarlo por todos lados hasta que abandonó la vida, que Dios Altísimo se apiade de él ${ }^{73}$.

Muy similar es la versión que Ibn al-Jațīb ofrece de los mismos hechos en otra obra suya, los $A^{\prime} m \bar{a} l$, en cuyo relato también implica directamente a Fāțima en el asesinato de Ibn al-Maḥrūq, como puede leerse a continuación:

El capítulo de la trama no fue otro que el asesinato del delegado (wakīl) y visir (șâhib al-'amr) [Ibn al-Mahrūq] con la ejecución de la orden de su sultán contra él, pues [resulta] que un grupo concreto de los esclavos de su padre [Ismā'îl I] lo habían vencido y lo habían separado de él, asesinándolo. Y es que él [Ibn al-Mahrūq] había entrado en la casa de la abuela del sultán $(d \bar{a} r$ al-ŷdda) para consultarle sobre los asuntos importantes, como de costumbre. Dos esclavos jóvenes (mamlūkāni hadatāani) de los que lo protegían lo asaltaron y lo mataron ante la presencia de la anciana

\footnotetext{
${ }^{71}$ Mernissi 2008,p. 78.

${ }^{72}$ Ibn al-Jatīb 2001, vol. I, pp. 533, 537; 1980, pp. 91 y 94, trad. 2010, pp. 197, 202. Así lo interpretó, de hecho, Casciaro 1947, p. 247; Arié 1990, pp. 205, 242.

${ }^{73}$ Ibn al-Jațīb 2001, vol. II, pp. 136-137; Arié 1990, p. 244.
} 
abuela (al-ŷadda al- $a \hat{y} \bar{u} z)$. Ello [sucedía] en la noche del día 2 del mes de muharram del año 729 [6 de noviembre de 1328] ${ }^{74}$.

En el coetáneo Magreb también se difundió este crimen político; sirva de ejemplo el relato que ofrece de él Ibn Jaldūn (m. 808/1406) en distintas obra suyas, en las que narra cómo sucedió:

El sultán Muhammad [IV] mató a traición a su visir Ibn al-Mạ̣rūq en su propia casa (bi-dari-hi) en el año [7]29, [pues] lo hizo llamar [a Ibn al-Mahrūq] para hablar, según su tía paterna (ammatihi) que lo dominaba [a Muhammad IV] junto con Ibn al-Maḥrūq. Le dio alcance con sus [esclavos] extranjeros, atravesándolo con los alfanjes hasta que murió ${ }^{75}$.

Resulta extraño que fuese, precisamente, una tía paterna la persona responsable de urdir tal crimen, pues no existe ninguna tía de este emir documentada en el árbol genealógico nazarí, donde tan sólo consta que Ismā īl I, padre de Muhammad IV, tenía un hermano llamado Muhammad ${ }^{76}$.

Al Oriente islámico llegaron también los ecos del asesinato perpetrado en la lejana Granada nazarí ${ }^{77}$. El informante de este acontecimiento fue el alfaquí y tradicionista granadino Ibn al-Hāâŷy al-Numayrī (m. 785/1383), quien había trabajado como secretario de la Alhambra en 734 (1333-4) y marchado a Oriente tres años más tarde para realizar la peregrinación a La Meca y formarse con grandes maestros. Fue, precisamente, en este periplo donde estudió el célebre cronista Šams al-Dīn al-Dahabī (m. 748/1347-8) y conoció personalmente a al-Ṣafadī (m. 764/1362) en El Cairo, donde se encontraba en el año $738(1362)^{78}$. De hecho, estos dos grandes autores transmiten en sus respectivas obras la versión del asesinato de Ibn al-Mạ̣rūq de boca del propio al-Numayrī, versiones en que no involucran a Fātima sino a la madre del sultán, 'Alwa. En cuanto al primero de ellos, al-Dahabī, narra lo siguiente:

A principios del año 729 (1328), Muḥammad [IV] se encolerizó con él [Ibn al-Mậrūq] y le preparó a dos valientes [hombres],

\footnotetext{
${ }^{74}$ Ibn al-Jațīb 2003, p. 297; Rubiera 1996, p. 188; 1975, p. 129 refiere este hecho aunque sin especificar la fuente de la que toma esta información.

${ }^{75}$ Ibn Jaldūn 2000, vol. IV, p. 222; Ibn Jaldūn 1971, vol. VII, pp. 373-374.

${ }^{76}$ Véase Boloix 2013,pp. 280-281.

77 Ženka 2012, pp. 120-121. Le agradezco explícitamente a mi compañero el Dr. Josef Ženka (Universidad de Praga) su gran generosidad al haberme facilitado la información procedente tanto de los textos de Ibn Jaldūn como de las fuentes orientales que ofrezco en este trabajo, y que él mismo ya expuso en su reciente artículo Ženka 2014, pp. 311-312, n. 16, de donde he tomado dichas referencias.

${ }^{78}$ Lirola, López 2004, pp. 341-343.
} 
llamados Gālib y Muqātil. Y cuando llegó el visir a sus guardias [personales], ambos le dijeron a éstos: "Inclinaos hasta que salga la madre del sultán (wālidat al-sulțān)". [Los guardas] salieron y [los dos valientes] cerraron la puerta tras ellos; después lo apresaron violentamente y lo mataron ${ }^{79}$.

Esta versión de los hechos es la misma que ofrece, aunque simplificada, Ibn Haŷar al- Asqalānī (m. 852/1449) ${ }^{80}$. Por su parte, al-Ṣafadī ${ }^{81}$ se limita a responsabilizar tan sólo a Muhammad IV del crimen.

Sea como fuere, lo cierto es que los datos que ofrece Ibn al-Hāâŷy al-Numayrī no son más fidedignos que los aportados por Ibn al-Jațīb, pues ambos fueron coetáneos y ninguno de ellos vivió dichos sucesos en persona. Por esta razón no descartamos que fuese Fātima la persona responsable de organizar la trama que acabó con la vida de Ibn al-Mahrūq en su propia casa (dār al-ŷadda).Y es que es cierto que, en la historia de las dinastías islámicas medievales, eran en realidad las madres las grandes veladoras del ascenso al poder de sus primogénitos y no dudaban en delinquir con tal de lograr la extensión del imperio materno. Sirvan de ejemplo los casos de Šagab, madre del califa 'abbāsí al-Muqtadir (295-320/909-932), quien no titubeó en ejecutar al cadí Aḥmad b. Ya qūb y a otros miembros de la autoridad religiosa para que su mencionado hijo fuese proclamado a pesar de ser menor de edad ${ }^{82}$; en el Imperio turco Otomano existen varios casos de este fenómeno, siendo uno de ellos el de la ambiciosa sultana Roxelana o Hürrem, concubina del sultán Sulaymān El Magnífico (1494-1566), quien no dudó en convencer a su esposo para que eliminase a Rüstem Pasha, un visir que no era de su agrado, ni en interceptar la relación que el soberano mantenía con su hijo Mușțafà, hijastro de Roxelana, llegando incluso a urdir, a sangre fría, el asesinato de este último ${ }^{83}$; tampoco debemos olvidar, en este sentido, el caso de la ya mencionada al-Jayzurān (m. 173/789), quien llegó a encargar el asesinato por asfixia de su propio hijo alHadī para que su vástago preferido, Hārūn al-Rašīd, se hiciese con el poder ${ }^{84}$; eso sin contar otros muchos casos similares que se dieron reiteradamente a lo largo de la historia de al-Andalus y del reino nazarí.

Sí es cierto que, en las situaciones previamente señaladas, llama la atención que las féminas más influyentes fuesen todas concubinas y no mujeres de sangre real. Esto nos lleva a aventurar que si aquéllas llegaron a al-

${ }^{79}$ Al-Dahabī s.d., pp. 375-376.

${ }^{80}$ Ibn Hayâar al- Asqalānī 1993, vol. III, p. 365.

${ }^{81}$ Al-Ṣafadī 1998, vol. III, p. 215.

${ }^{82}$ Mernissi 2008, pp. 77-78; El Cheikh 2002, pp. 141-143; 2004, pp. 147-161.

${ }^{83}$ Parker 2011; Akşit 2012, pp. 91-103.

${ }^{84}$ Roded 1999, pp. 87-88; Mernissi 2008, pp. 77, 93-121. 
canzar tanto ascendiente en los asuntos cortesanos, con más razón lo tendrían las princesas nacidas en el seno de la propia familia reinante. En el caso que nos compete, diversas razones apuntan a que la abuela del sultán protagonista, Fātịma, pudo haber planeado dicho crimen; por un lado, ella fue una gran excepción a todas las reglas, políticas y familiares, de la dinastía; y, por otro, no hay que olvidar que era una mujer muy conocida por el propio Ibn al-Jațīb, quien, de hecho, en su funeral pronunció en persona el treno que había compuesto a su muerte. Tal vez esta cercanía sea motivo suficiente para validar la versión de este cronista por encima de las otras.

A pesar de la protección de Fātịma, su abuela, Muhammad IV tan sólo llegaría a reinar ocho años, pues a la edad de dieciocho fue asesinado como lo había sido su padre. En su caso, fue víctima de una emboscada en el río Guadiaro cuando regresaba de Gibraltar, momento en el que fue atacado con lanzas por unos asesinos y rematado por un esclavo renegado llamado Zayyānn ${ }^{85}$. Ello sucedía un 13 de $\underline{d} \bar{u} l$-hîŷy $a$ de 733 (25 de agosto de 1333), siendo enterrado en Málaga. Fāțima quedaba, de nuevo, en primera línea de la corte nazarí. Y es que, el mismo día del asesinato repentino de Muhammad IV, su otro nieto Yūsuf I (733-755/1333-1354) era proclamado emir siendo también menor de edad, pues tan sólo contaba con quince años.

En esta ocasión, Fāțima compartió de nuevo la tutela del nuevo soberano con un hââyib o chambelán llamado Riḍwān (m. 760/1359) ${ }^{86}$. De hecho, Ibn al-Jațīb señala cómo, debido a su inmadurez, el nuevo emir no tomaba nada de su patrimonio ni se ocupaba de asunto alguno que fuese de su corte, así como tampoco tomaba más decisión que sobre los alimentos que había sobre su mesa de puertas para adentro de su alcázar hasta que alcanzó la adultez ${ }^{87}$. Sin embargo, las fuentes no son muy explícitas al identificar en qué hechos concretos se materializó la actividad política de esta sultana en dicha época, que tal vez pudo ser poco intensa debido a su avanzada edad, pues cuando Yūsuf I subió al poder esta mujer debía de contar con más de setenta años lunares. María Jesús Rubiera llegó a sugerir la posible participación de Fāțima, a la sombra de Yūsuf I, en el plan de construcción de los palacios de la Alhambra que este soberano ordenara erigir, entre ellos el de Comares, siguiendo en ello la política arquitectónica de Muhammad III, su hermano uterino ${ }^{88}$; pero, en realidad, no existen evidencias de dicha iniciativa.

${ }^{85}$ Ibn al-Jațịb 2001, vol. I, pp. 540-541; 1980, pp. 96-97, trad. 2010, p. 205-206; 2004, p. 304. Sobre el asesinato de este emir nazarí, véase Vidal 2004, pp. 364-366.

${ }^{86}$ Para su biografía, véase Ibn al-Jațīb 2001, vol. I, pp. 506-513.

${ }^{87}$ Ibn al-Jatịib 2004, p. 305; Rubiera 1975, p. 129.

${ }^{88}$ Rubiera 1996, p. 188. 
De lo que sí hay certeza es del gran reconocimiento rendido a Fātima en el momento de su muerte, acaecida durante el reinado de su nieto Yūsuf I, al alba del día 7 de $\underline{d} \bar{u} l$-ḥîŷya del año 749 (26 de febrero de 1349), con más de noventa años lunares de edad. Ibn al-Jațīb le dedicó unas hermosas palabras en las que perfiló la gran personalidad de esta mujer y resumió su vida, cuya traducción podemos leer a continuación:

Su madre, nobilísima dama emparentada con los reyes [por los cuatro costados], fue Fātima, hija del Emir de los Creyentes Abū Abd Allāh [Muhammad II]. Ella era la flor y nata del reino, la perla central del collar [de la dinastía], el orgullo [de las mujeres] del harén, la ambiciosa del honor y el respeto, el vínculo [que aseguraba a los súbditos] la protección [de los reyes] y el [vivo] recuerdo de la herencia [de la familia real]. Su vida, [muy] solicitada del buen consejo, como un catálogo de moralejas y un epitafio de antepasados [ilustres], se ha prolongado hasta que falleció en tiempos de su nieto, el sultán Abū l-Haŷŷâŷy [Yūsuf I] -ique Dios se apiade de ella!-, con más de noventa años de edad ${ }^{89}$.

Los detalles que Ibn al-Jatīb ofrece sobre el funeral de Fātịma revelan la gran estima en la que era tenida esta mujer. Según el visir lojeño, la afluencia de gente a sus exequias corrió pareja a su dignidad y a su enorme legado. Otro detalle significativo es que Fāțima fuese inhumada en el cementerio real nazarí de la Rawda, dentro de la Alhambra, donde ni su marido, ni sus propios hermanos (Muḥammad III y Nașr), ni su nieto Muhammad IV, todos ellos sultanes, habían recibido sepultura, pues recordemos que habían sido relegados al cementerio secundario de la Sabīka ${ }^{90}$. Fāṭima era, pues, enterrada junto a su padre, Muḥammad II, y su hijo, Ismā îl I. De hecho, las intervenciones arqueológicas realizadas en 1892 por el Arquitecto Conservador de la Alhambra Mariano Contreras descubrieron un total de treinta sepulturas vacías de adultos y ocho de niños, todas ellas pertenecientes a miembros de la dinastía nazarí, siendo que los únicos restos humanos encontrados pertenecían, curiosamente, a una mujer ${ }^{91}$.

Los honores rendidos a esta sultana no quedaron ahí, pues durante sus exequias fúnebres Ibn al-Jațīb pronunció en público un sentido treno de cuarenta y un versos que él mismo había compuesto y que se conserva íntegramente en su $D \bar{\imath} w \bar{a} n$ de poesía ${ }^{92}$. Ésta fue, sin duda, una gran distinción

\footnotetext{
${ }^{89}$ Ibn al-Jațīb 2001, vol. I, p. 378; Boloix 2013, p. 66.

${ }^{90}$ Ibn al-Jațīb 2001, vol. I, p. 379; Boloix 2013, p. 66.

${ }^{91}$ Torres 1981, pp. 13-33.

${ }^{92}$ Ibn al-Jațîb 1989, vol. I, pp. 396-398 (núm. 302); 2001 vol. I, p. 379; traducida por primera vez del árabe al castellano por Boloix 2013, pp. 268-270.
} 
que pocas mujeres de la realeza medieval llegaron a alcanzar. De hecho, era una inviolable cuestión de respeto no aludir a las mujeres nobles en escritos ni mencionar tampoco sus nombres, costumbre que ni siquiera encontraba salvedad en las elegías pronunciadas con motivo de sus óbitos ${ }^{93}$. Sin embargo, el caso de Fāṭima fue, una vez más, la gran excepción de la regla. Dicho treno rezaba asîn ${ }^{94}$.

Me ha llegado una noticia cierta de este tiempo,

pues sabemos que las criaturas están en manos del destino.

Confiamos en el mundo, engañados por su coerción,

pero a ti debe bastarte aquel que espera [de él] el cumplimiento de la traición.

Aplazamos con tesón el tiempo neciamente,

día tras día, mes tras mes.

Deseamos ardientemente [todo] lo perecedero: las ambiciones y el deseo, y rechazamos lo que permanece. ¡Qué derroche de vida!

Entregamos a los nobles seres queridos a la muerte $\mathrm{y}$, luego, nos solazamos y nos despreocupamos del asunto.

Es el tiempo, en cuyas vicisitudes no acaece nada nuevo, y que no se priva de ningún suceso nefasto.

Entre los infortunios que asaltan de noche hay pugna por la prioridad, como el mérito en el alto rango de quien lo arrebata [la muerte].

¿No ves que los cuarteles de la gloria están en la miseria y que de sus árboles frondosos se secó todo el que verdeaba?

Y apareció en el rostro de la grandeza una aflicción, al punto de fruncir el entrecejo después de la jovialidad y la alegría.

Gran señora nuestra, el quedarnos exentos de las aflicciones de la natural paciencia es la [única] satisfacción [que a ti pudiéramos dar].

Te perdimos; no perdieron [tanto] los ojos al quedar privados de su luz, pues fuiste para nosotros luz que iluminaba [el camino] a quien viajaba de noche.

¡Caray con la depravada muerte! ¿Cómo no se amilanó ante tu morada, rodeada de prohibiciones y órdenes?

¿Cómo el revés de la muerte pudo, empeñado, afilarse a través de las blancas hojas [de las espadas] y las oscuras lanzas?

Son tupidos los velos de la sólida religión.

¡[Pero] cuántos velos hay, tras ellos, para el poder y la gloria!

Preparamos las nobles lanzas, pero el mandato de Dios viene de noche, sin que lo sepamos ${ }^{95}$.

Es el destino, cuya sentencia fluye sobre las criaturas, quedando equiparadas la gloria de la riqueza y la vileza de la pobreza.

[Dicho destino] lanzó la muerte a Tubba ${ }^{966}$ premeditadamente, no habiendo para sus seguidores victoria alguna en tal desgracia;

\footnotetext{
${ }^{93}$ Garulo 2004, p. 34; Fórneas 1989, pp. 77-103.

${ }^{94}$ Agradezco a los profesores Fernando Velázquez Basanta (Universidad de Cádiz) y Saleh al-Zahrani (Universidad de Riyad, Arabia Saudí) su ayuda en la traducción de este poema.

${ }^{95}$ Este verso de Ibn al-Jațîb está inspirado en un conocido poema del gran poeta árabe alMutanabbī, dedicado a la muerte de la madre de Sayf al-Dawla.

${ }^{96}$ Soberano sudarábigo.
} 
derribó, con su adversidad, a Anūširwān $\operatorname{Cosrroes}^{97}$, [abandonándole] roto, y no dejó palacio alguno al César.

Cierto es que el Islam y su gente sufrieron tu pérdida; un tesoro de renombre y notoria mención.

[La sultana Fāṭima] fue única, sobrepasando a las mujeres de su época como sobrepasa a las otras noches la Noche del Destino ${ }^{98}$.

¿Acaso no rebaja el nombre femenino del sol su rango

y no eleva el nombre masculino de la luna llena su categoría? ${ }^{99}$

La firmeza de opiniones, el mérito de la política

y el orgullo de un origen [familiar] son lo máximo de la excelencia.

Un $d \bar{\imath} w a \bar{n}$ de gloria, cuyas páginas incluían

[la historia] íntima de los gloriosos Reyes nazaríes ${ }^{100}$.

¿Cómo puedo elogiar tu feliz Alteza?

¿Por [el hecho de] mantener la acostumbrada protección? ¿Por guardar los favores?

¿Por ser amparo para los refugiados o por socorro para los necesitados?

Pienso que [siempre] se espera el retorno del viaje de la vida terrenal

[pero no del de la muerte] hasta el día de la resurrección.

Vuelve [pues] al palacio real, ensombrecido por ti,

aunque sea a modo de santuario para tu espectro, que viaja de noche.

¡Pues cuántos corazones hay en él, palpitando por tu lejanía!

¡[Cuánta] congoja ardiendo, [cuántas] lágrimas fluyendo!

¡[Cuántas uniones en él] que separó la mano de la lejanía,

y maravillosas vistas que la mano del destino alteró!

[¡Cuántas] moradas del reino [hay en él] cuyos rincones se volvieron baldíos, apareciendo el halo de un palacio sin luna llena!

No fuiste sino el sol por el que viven las criaturas, pese a su elevada alteza y su alto rango.

¡Y cuán difícil es compararte con el sol,

en perfección sin defecto, en utilidad sin perjuicio!

Al alzarte sobre los cuellos, cargamos con una nube de bendita

lluvia y sagradas gotas.

Y cuando arribamos a tu tumba en las densas oscuridades

vimos el ocaso del sol al salir el alba.

Si una sepultura se convirtiese para la gente en una alquibla ${ }^{102}$, colocaríamos nuestro oratorio en dicho sepulcro.

${ }^{97}$ Uno de los reyes más importantes y célebres de la dinastía sasánida del segundo Imperio Persa, que gobernó entre 531 y 579.

${ }_{98}$ Este verso fue traducido aisladamente por Rubiera 1996, p. 189. La llamada "Noche del Destino" (Laylat al-Qadr) es aquella en la que tuvo lugar la primera revelación del Corán al profeta Mahoma, razón por la que es considerada la más insigne noche de la historia del Islam.

99 Verso inspirado, asimismo, en uno previo del poeta al-Mutanabbī, procedente del mismo poema elegiaco dedicado a la muerte de la madre de Sayf al-Dawla.

100 En este hemistiquio, los reyes nazaríes son mencionados como Gālibies, denominación derivada del lema oficial de la dinastía la locución $L \bar{a}$ Gălib illà Allāh ("No hay más vencedor que Dios”). Sobre esta divisa, véase Boloix 2006, pp. 196-199.

${ }^{101}$ En la edición del texto árabe, falta el segundo hemistiquio de este verso.

102 Punto del horizonte o lugar de la mezquita orientado hacia la Meca hacia donde los musulmanes se dirigen cuando rezan. 
Y si las criaturas hallaran el camino conducente a un cementerio que contuviese tu sepulcro, rodeado de virtud y de piedad,

lo circunvalarían siete [veces], rezarían la oración de los peregrinos en la $\mathrm{Meca}^{103}$,

y se pondrían el $i h r a \bar{a} m^{104}$; solo así ganarían la recompensa [de Dios].

Tu alteza protegió a la firmeza de[1 sultán] Yūsuf [I],

el rey piadoso, descendiente de tu pura excelencia.

Pero la sentencia surgió de Dios,

haciéndose imperativo reaccionar ante ella con resignación, paciencia y gratitud.

Recibe este elogio por parte de un triste siervo de tu Reino;

loor que, como el céfiro, sopla sobre las flores.

Si pudiera compensarte suficientemente con cuanto mereces,

lo haría según exige tu grandioso rango, no según el mío.

[Pues], ;por Dios!, que no he satisfecho el deber de ofrecerte lo merecido aunque, al menos, esta [elegía] pueda servirme como disculpa.

Esta elegía va seguida de una parte en prosa, también compuesta por Ibn al-Jațīb, que tal vez fue grabada en la propia lápida de la sultana Fātịma, lamentablemente no conservada. Llama la atención cómo el texto insiste en que esta mujer descendía de la rama "legítima" nazarí, la del emir Muhammad I, así como en el provecho que sus descendientes, y en concreto su nieto Yūsuf I, sacaron de la experiencia política y de los grandes méritos que adornaban a su persona, según expresa el siguiente párrafo ${ }^{105}$ :

La noble y casta sultana Fātima, hija del Emir de los musulmanes Abū 'Abd Allāh [Muhammad II], hijo del Emir de los musulmanes Abū Abd Allāh [Muhammad I] al-Gālib bi-Llāh, era lo más granado de las mujeres de los reyes, la protectora del régimen del emirato, [amén de] una custodia para los lazos familiares, un vínculo para el respeto, una personificación del favor, un refugio para las familias [nobles] y una emulación de los antepasados honestos, en la integridad del espíritu, la altura de miras, la firmeza de la religión, el levantamiento del velo [de las cosas que separan a los hombres de Dios], la ejecución de la determinación y el aviso de la paciencia. Falleció al cuidado de su nieto, el Emir de los musulmanes Abū l-Haŷŷâŷy [Yūsuf I], que persiste en su piedad, que procura su plegaria, que aprovecha su experiencia y su epitafio, al tiempo que se ocupa de su inhumación en el Cementerio del Jardín, dentro de la Alhambra, al alba del domingo día 7 de $\underline{d} \bar{u} l$-hị̂ŷya del año 749 (26 de febrero de 1349) ${ }^{106}$.

${ }^{103}$ Es decir, harían la talbiya u oración que los peregrinos musulmanes pronuncian en La Meca.

104 Vestimenta blanca y uniforme que llevan los musulmanes durante los ritos de peregrinación en La Meca. Dicha indumentaria simboliza que el peregrino ha entrado en estado sacro, tras haber realizado la ablución mayor o lavado ritual de todo el cuerpo.

105 Ibn al-Jațîb 2001, vol. I, p. 379; traducida por primera vez del árabe al castellano por Boloix 2013, p. 271.

106 Día que, según Ubieto 1984, vol. I, p. 409, fue viernes. 
Tanto la riqueza de este merecido epitafio como los motivos literarios que en él confluyen podrían dar de sí para a un estudio más detallado; sin embargo, la limitación de espacio nos obliga a poner punto final a este estudio sobre Fātima bint al-Aḥmar con el desenlace de su propia vida. No olvidemos que con el fallecimiento de esta sultana se cerraba una importantísima página de los anales de la historia nazarí, a la vez que se sentaba un precedente, único e irrepetible, que las princesas posteriores de la dinastía difícilmente lograron igualar.

\section{CONCLUSIÓN}

La información expuesta a lo largo de este trabajo nos permite afirmar, por un lado, que la Historia siempre estará coja sino consideramos la aportación femenina tanto a su desarrollo como a su discurso; y, por otro, que en la historia del reino nazarí de Granada las mujeres no estuvieron completamente al margen de los asuntos políticos, en los que consta que participaron, en mayor o menor medida, y con un considerable nivel de influencia. La figura protagonista de este trabajo, Fāțima bint al-Aḥmar, fue sin lugar a dudas el caso más emblemático de esta clara realidad. Las mujeres nazaríes del siglo XIII apenas tuvieron al parecer trascendencia política, como parece indicar la ausencia de referencias a sus actuaciones en los textos. Pero en el siglo XIV se produce un giro radical en este escenario que inaugura, precisamente, la sultana Fātima.

El hecho de que los retales de su vida, su personalidad y su intensa actividad política hayan quedado reflejados en distintas fuentes árabes puede ser considerado el indicio más evidente de su enorme influencia en la corte de la Alhambra y de su determinante paso a la posteridad. Curiosa resulta, asimismo, la propia denominación de sultana (sulțāna) que acompaña explícitamente al nombre de esta fémina nazarí en los textos de Ibn al-Jațīb; cabe señalar que pocas son las princesas nazaríes que hallamos referidas con tal título real en los textos árabes, por lo que su aplicación a esta mujer pudo deberse a una intención, por parte de este cronista, de reconocer explícitamente el papel y la autonomía Fāțima en el ejercicio del poder, que tantas veces desempeñó en solitario.

Como hemos podido advertir en los datos ofrecidos, la intervención de esta mujer en los asuntos cortesanos nazaríes no fue un hecho aislado ni puntual, pues también han quedado registradas las actuaciones de féminas en los contextos de otras dinastías islámicas medievales, lo que nos lleva a concluir que este fenómeno fue mucho más frecuente de lo que los textos nos pueden inducir a pensar. De hecho, los tratados árabes de política sitúan 
estas prácticas al margen de sus teorizaciones. Es, por lo tanto, injusto que tales actuaciones continúen siendo tildadas de "intrigas" cuando las realiza una mujer. En lo que respecta a Fāṭima, tuvo la suerte de vivir, en primera persona, el reinado de su padre Muhammad II y el de su hermano preferido, heredero de este último, Muhammad III, contagiándose de las experiencias políticas de ambos. Asimismo, las circunstancias la llevaron a alinearse junto a su marido, el arráez Abū Sa īd Faraŷ, contra el gobierno de su otro hermano non grato Nașr, sin llegar a perder peso político durante dicho proceso. Sin embargo, su mayor logro fue elevar al poder, en colaboración con su esposo, a su hijo Ismā îl I, desafiando con este viraje las reglas patriarcales que determinaban la sucesión dinástica. Gracias a su aportación, por primera vez en la historia nazarí un emir heredaba el reino y el derecho a reinar directamente de la sangre real de su madre. Este inusual fenómeno marcó, por lo tanto, un antes y un después en la trayectoria de este emirato, sentando un precedente que legitimaría decisiones similares tomadas en el seno de este linaje en generaciones posteriores.

El supuesto cambio de rama reinante dentro de la casa real de la Alhambra ha sido otra cuestión digna de análisis en este trabajo. Aunque hasta ahora se haya interpretado que, con el ascenso de Ismāî̀ I al poder, se produjeron un cambio y una ruptura con respecto a la línea de sultanes anterior (aquélla inaugurada en el siglo XIII por el fundador de la dinastía, Muhammad I), tal vez haya que replantearse esta fosilizada, y trasnochada, conclusión. No olvidemos que Fāṭima transmitió, precisamente, a su hijo la legitimidad para reinar ante el hecho de que ninguno de sus dos hermanos varones, Muhammad III y Nașr, habían dejado descendencia a su muerte, lo que conducía a la continuación de la dinastía nazarí a un callejón sin salida. Tal vez, a la luz de nuestros tiempos, haya que entender que la inesperada proclamación de Ismā īl I no vino sino a solventar un problema de sucesión dinástica truncada de manera completamente legítima pues, por parte de madre, Ismā īl I era sucesor directo del primer emir nazarí, asegurando su reinado la continuación de la línea reinante iniciada tiempo atrás.

Las actuaciones de Fāṭima una vez asesinado su hijo, Ismāî̀l I, constituyen una importante evidencia de su peso político y de su capacidad de decisión en momentos clave que recuerdan al proceder de figuras femeninas tan emblemáticas de la Historia del Islam como la ya mencionada alJayzurān, protectora madre del célebre califa 'abbāsí Hārūn al-Rašīd. Estas aptitudes se hacen especialmente patentes en Fātima en tiempos de su nieto Muhammad IV, durante cuya minoría de edad dicha sultana no sólo compartió su tutela política sino que tomó determinaciones muy importantes. Sin duda, la más llamativa fue aquella que acabó con la vida, y la extrema injerencia, del controvertido visir Ibn al-Mahrūq, quien amenazaba con acaparar 
y hasta poner en peligro el reinado del joven soberano. El hecho de que el mencionado ministro viese en Fāțima un apoyo para sus propios intereses, y que frecuentase su casa para debatir con ella asuntos importantes de gobierno, viene a insistir en la enorme capacidad, prestigio e influencia política de esta mujer.

La labor de asesoramiento de esta sultana en los asuntos cortesanos nazaríes debió de prolongarse, a pesar de su avanzada edad, durante el reinado de su segundo nieto Yūsuf I, cuya firmeza protegió como descendiente que era de su pura excelencia, parafraseando a Ibn al-Jațīb. Así lo reflejan los múltiples elogios que este último le rendía tanto en la endecha fúnebre como en la composición prosística que dedicó a esta mujer a su muerte. Este cronista no sólo la consideraba luz que iluminaba [el camino] a quien viajaba de noche o una fémina única, sobrepasando a las mujeres de su tiempo; también insiste en los méritos que engalanaban su persona, como la firmeza de opiniones, el mérito de la política y el orgullo de un origen [familiar], lo máximo de la excelencia, a la vez que la erige en la protectora del régimen del emirato y en un catálogo de moralejas y un epitafio de antepasados [ilustres]; en otras palabras, en el vínculo [que aseguraba a los súbditos] la protección [de los reyes] y el [vivo] recuerdo de la herencia [de la familia real]. A pesar de esta intensa actividad política, reconocida en el momento de su desaparición, sorprende, a la luz de nuestros tiempos, que no haya quedado reflejada en los textos árabes ninguna iniciativa de esta sultana como mecenas del arte, ni que tampoco existan referencias en los textos a edificios erigidos en su nombre, ya fuesen palaciegos, mezquitas o instituciones piadosas, si bien este tipo de menciones son textualmente inexistentes en lo que a las mujeres de la dinastía nazarí se refiere.

Los honores recibidos por la sultana Fāṭima no pudieron ser, por tantas y tantas razones aludidas y por tantas otras que han quedado obviadas en páginas nunca escritas, menores que los merecidos por un sultán. Con su desaparición, la Alhambra que la vio nacer quedaba sin luna llena y ensombreci$d a$; su sepulcro, tornado en eterno santuario de peregrinación; y su memoria, viva en el futuro trascurso de la propia dinastía, en la que muchas mujeres portaron su nombre y decidieron sobre la política nazarí como ella lo había hecho. Y es que, a partir de la existencia de Fātịma, se abrió un punto de inflexión gracias al cual buena parte del futuro de la dinastía de la Alhambra estuvo, sin duda, en manos de sus mujeres. 


\section{BIBLIOGRAFÍA CITADA}

\section{FUENTES}

Al-Bunnāhī (1863), Nuzhat al-bașā'ir wa-l-abșār, ed. parcial por Marcus Joseph Müller, Die letzten Zeiten von Granada, Múnich, Christian Kaiser.

Al-Dahabī, Šams al-Dīn (s.d.), Dayl ta'rīj al-Islām, ed. Māzin b. Sālim Bāwaz̄ir, Riyad, Dār al-Mugnī li-l-Našr wa-l-Tawzī .

Al-Maqqarī (1968), Nafh al-țīb min gușn al-Andalus al-ratīb wa-dikr wazīrihā Lisān al-Dīn Ibn al-Jaṭīb, ed. Iḥsān 'Abbās, 8 vols., Beirut, Dār Șādir.

Al-Șafadī (1998), A yān al-'aṣr wa-a'wān al-nașr, ed. 'Alī Abū Zayd et alii, 6 vols., Beirut - Damasco, Dār al-Fikr al-Mu āșir-Dār al-Fikr.

Ibn al-Jațīb (1980), Al-Lamha al-badriyya fi l-dawla al-nașriyya, ed. Muhibb al-Dīn al- Jațīb, Beirut, Dār al-Afāq al-Ŷadīda; trad. española José María Casciaro, Emilio Molina López (2010), Historia de los Reyes de la Alhambra, Granada, Universidad.

Ibn al-Jațīb (1989), Dīwān Lisān al-D̄̄n Ibn al-Jațīb al-Salmān̄̄, ed.

Muḥammad Miftāḥ, 2 vols., Casablanca, Dār al-Taqāfa li-l-Našr wa1-Tawzī .

Ibn al-Jațīb (2001), Al-Ihāṭa fì ajbār Garnāta, ed. Muhammad 'Abd Allāh 'Inān, 4 vols., El Cairo, Maktaba al-Janŷ̄i.

Ibn al-Jațīb (2004), Kitāb A'māl al-A lām fì man būyi a qabla al-iḥtilām min mulūk al-Islām, ed. E. Levi-Provençal, El Cairo, Maktabat al-Taqāfa al-Dīniyya.

Ibn Hajar al- Asqalānī (1993), Al-Durar al-kāmina fì a yān al-mi'a al-tāmina, 5 vols., Beirut, Dār al-Ŷ̄ill.

Ibn Jaldūn, A Abd al-Raḥmān (s.d.),Mawṣū at al-'allāma, 7 vols., El Cairo, Dār al-Kitāb al-Mișrī - Beirut, Dār al-Kitāb al-Lubnānī.

Ibn Jaldūn, ‘Abd al-Raḥmān (1971), Kitāb al- ibar, 7 vols., Beirut, Mu 'assasat al-A lamī li-l-Maṭbū āt.

Ibn Jaldūn, 'Abd al-Raḥmān (2000), Ta'rīj Ibn Jaldūn al-musammà Dīwān al-mubtada wa-l-jabar fì ta'rīj al-'arab wa-l-barbar wa-man ‘āṣarahum min $\underline{d} a w \bar{\imath}$ al-ša'n al-akbar, ed. Jalīl al-Šihāda, 8 vols., Beirut, Dār al-Fikr li-1-Tỉbā a wa-1-Našr wa-1-Tawzī .

Ibn Manzūr (1956), Lisān al-'Arab, 15 vols., Beirut, Dār Șādir.

Crónica de don Alfonso el Onceno (1787), ed. Francisco Cerdá y Rico, Madrid, Imprenta de don Antonio de Sancha. 
BIBLIOGRAFÍA

Abbott, Nabia (1942), Women and the State in Early Islam: The Umayyads, "Journal of Near Eastern Studies" 1, pp. 341-368.

Abbott, Nabia (1946), Two Queens of Baghdad: Mother and Wife of Hārūn al-Rashīd, Chicago, University of Chicago Press.

Akşit, İlhan (2012), The Mystery of the Ottoman Harem, Estambul, Akşit Kültür ve Turizm Yayimcilik.

Arié, Rachel (1990), L’Espagne musulmane au temps des Naṣrides (12321492), París, De Boccard.

Ávila, María Luisa (1989), Las mujeres “sabias” en Al-Andalus, en La mujer en Al-Andalus: reflejos históricos de su actividad y categorías sociales, Madrid, Universidad Autónoma - Sevilla, Editoriales Andaluzas Unidas, pp. 139-184.

Bariani, Laura (1996), De las relaciones entre Șubh y Muhammad Ibn Ab̄ 'Āmir al-Manșūr con especial referencia a la "ruptura” (waȟša) en 386-388/996-998, “Qurțuba” 1, pp. 39-57.

Bariani, Laura (2005), ¿Fue Șubh “la plus chère des femmes fécondes”? Consideraciones sobre la dedicatoria de las arquillas califales del Instituto de Valencia de don Juan y de la Iglesia de Santa María de Fitero, "Al-Qanțara" 16, pp. 299-315.

Boloix Gallardo, Bárbara (2006), De la taifa de Arjona al reino nazarí de Granada (1232-1246). En torno a los orígenes de un estado y de una dinastía, Jaén, Instituto de Estudios Giennenses.

Boloix Gallardo, Bárbara (2007), Muhammad I y el nacimiento del al-Andalus nazarí (1232-1273). Primera estructura del reino de Granada, Granada, Universidad de Granada.

Boloix Gallardo, Bárbara (2013), Las sultanas de la Alhambra. Las grandes desconocidas del Reino Nazarí de Granada (siglos XIII-XV), Granada, Comares - Patronato de la Alhambra y el Generalife.

Boloix Gallardo, Bárbara (2014), Beyond the Haram. Ibn al-Khațib and his Privileged Knowledge of the Royal Nasrid Women, en Boloix Gallardo, Bárbara (ed.), Praising the "Tongue of Religion". Essays in Honor of the 700th Anniversary of Ibn al-Khatīb's Birth (1313-2013), Leiden - Boston, Brill, pp. 384-403 (Medieval Encounters; 20/4-5).

Boloix Gallardo, Bárbara (2015), Fès, point de rencontre entre sultanes nasrides et mérinids, en Páez, Jerónimo (ed.), Fès, 1200 ans d'Histoire, Granada, Almed, vol. I, pp. 301-315.

Boloix Gallardo, Bárbara (2016), Presencia e importancia de la mujer en el Musnad de Ibn Marzūq al-Tilimsān̄̄ "Anaquel de Estudios Árabes" 27, pp. 7-28. 
Boloix Gallardo, Bárbara (en prensa), Los comienzos del Reino Nazarí de Granada. Vida y reinado de Ibn al-Ahmar (1196-1273), Granada, Universidad.

Bosworth, Clifford E.; Donzel, E. van; Lewis, B.; Pellat, Ch. (eds.) (1978), Encyclopaedia of Islam, Leiden, Brill.

Calero Secall, María Isabel (ed.) (2006), Mujeres y sociedad islámica: una visión plural, Málaga, Universidad de Málaga.

Casciaro, José María (1947), El visirato en el reino nazarí de Granada, Madrid, Instituto Nacional de Estudios Jurídicos.

Echevarría Arsuaga, Ana (2006), Caballeros en la frontera. La guardia morisca de los reyes de Castilla, Madrid, UNED.

El Cheikh, Nadia María (2002), Women's History: A Study of al-Tanūkhī, en Deguilhem, Randi; Marín, Manuela (eds.), Writing the Feminine: Women in Arabic Sources, Londres, I. B. Tauris, pp. 129-148.

El Cheikh, Nadia María (2004), Gender and Politics in the Harem of al-Muqtadir, en Brubaker, Leslie; Smith, Julia (eds.), Gender in the Early Medieval World: East and West, 300-900, Cambridge, Cambridge University Press, pp. 147-161.

Fórneas Besteiro, José María (1989), Acerca de la mujer musulmana en las épocas almorávide y almohade: elegías de tema femenino, en Viguera Molins, María Jesús (ed.), La mujer en al-Andalus. Reflejos históricos de su actividad y categorías sociales, Madrid - Ediciones de la Universidad Autónoma, Sevilla - Ediciones Andaluzas Unidas, vol. I, pp. 77-103.

Garulo, Teresa (2004), Women in Medieval Classical Arabic Poetry, en Deguilhem, Randi; Marín, Manuela (ed.), Writing the Feminine: Women in Arabic Sources, Londres, I. B. Tauris, pp. 25-40.

Lirola Delgado, Jorge; López y López, Ángel Custodio (2004), Ibn al-Hāâŷy al-Numayrī, Abū Isḥāq, en Lirola Delgado, Jorge; Puerta Vilches, José Miguel (eds.), Biblioteca de al-Andalus, Almería, Fundación Ibn Tufayl de Estudios Árabes, pp. 341-351.

Manzano Rodríguez, Miguel Ángel (1992), La intervención de los benimerines en la Península Ibérica, Madrid, CSIC.

Marín Niño, Manuela (1997), Una vida de mujer: Șubh, en Ávila, María Luisa; Marín, Manuela (eds.) Biografías y género biográfico en el Occidente islámico, Madrid, CSIC, pp. 425-445 (EOBA; 8).

Marín Niño, Manuela (2000), Mujeres en al-Andalus, Madrid, CSIC.

Marín Niño, Manuela (2006), Vidas de mujeres andalusies, Málaga, Sarriá.

Martin, Therese (2005), The Art of a Reigning Queen as Dynastic Propaganda in Twelfth-Century Spain, "Speculum" 80, pp. 1134-1171.

Martin, Therese (2006), Queen as King: Politics and Architectural Propaganda in Twelfth-Century Spain, Leiden - Boston, Brill. 
Martin, Therese (2012), Reassessing the Roles of Women as "Makers" of Medieval Art and Architecture, Leiden - Boston, Brill.

Martínez Enamorado, Virgilio (1994), Granadinos en la Riḥla de Ibn Batțūta: apuntes biográficos, "Al-Andalus-Magreb” 2, pp. 203-221.

Mernissi, Fatima (2008), Las sultanas olvidadas, Barcelona, El Aleph Editores.

Parker. P. J. (2011), Roxelana and Sulayman, Londres - Nueva York, Raider Publishing International.

Perrot, Michelle (2009), Mi historia de las mujeres, Buenos Aires, Fondo de Cultura Económica.

Puente González, Cristina de la (2007a), Límites legales del concubinato: normas y tabúes en la esclavitud sexual según la Bidāya de Ibn Rušd, "Al-Qanțara" 28/2, pp. 409-433.

Puente González, Cristina de la (2007b), Mujeres cautivas en "la tierra del Islam", "Al-Andalus-Magreb" 14, pp. 19-37.

Puente González, Cristina de la (2013), Free fathers, Slave Mothers, and their children: a Contribution to the Study of Family Structures in Al-Andalus, "Imago Temporis. Medium Aevum" 7, pp. 27-44.

Roded, Ruth (ed.) (1999), Women in Islam and the Middle East, Londres Nueva York, I. B. Tauris.

Rubiera Mata, María Jesús (1975), El arráez Abū Sà̄ $\bar{\imath}$ Faraŷ b. Ismāīl b. Nașr, gobernador de Málaga y epónimo de la segunda dinastía nazarí de Granada, "Boletín de la Asociación Española de Orientalistas" 11, pp. 127-133.

Rubiera Mata, María Jesús (1978), El vínculo cognático en al-Andalus, en Actas del I Congreso de Historia de Andalucía. Andalucía medieval, Córdoba, Monte de Piedad - Caja de Ahorros, vol. I, pp. 121-124.

Rubiera Mata, María Jesús (1989), Oficios nobles, oficios viles, en Viguera Molíns, María Jesús (ed.), La mujer en Al-Andalus: reflejos históricos de su actividad y categorías sociales, Madrid, Ediciones de la Universidad Autónoma - Sevilla, Ediciones Andaluzas Unidas, pp. 71-76.

Rubiera Mata, María Jesús (1992), La voz de las poetisas en el Al-Andalus y la problemática de la voz femenina de literaria medieval, en La voz del silencio, Madrid, Asociación Cultural al-Mudayna, vol. I, pp. 65-70.

Rubiera Mata, María Jesús (1996), La princesa Fātima bint al-Aḥmar, la "María de Molina" de la dinastía nazarí, "Medievalismo" 6, pp. 183-189.

Salicrú i Lluch Roser (1998), El sultanat de Granada i la Corona d'Aragó (1410-1458), Barcelona, IMF-CSIC. 
Salicrú i Lluch Roser (2011), Sultanas emergentes: visualizaciones de la mujer musulmana en las fuentes cristianas, en Toro Ceballos, Francisco; Rodríguez Molina, José (coords.), VIII Estudios de Frontera. Mujeres y frontera, Jaén, Diputación Provincial, pp. 477-483.

Shatzmiller, Maya (2007), Her day in Court: Women's Property Rights in Fifteenth-Century Granada, Cambridge, Harvard University Press.

Torres Balbás, Leopoldo (1981), Paseos por la Alhambra. Una necrópolis nazarí: la Rauda, en Obra dispersa, Madrid, Instituto de España, vol. II-9, pp. 13-33.

Ubieto Arteta, Antonio-Paulo (1984), Tablas teóricas de equivalencia diaria entre los calendarios islámico y cristiano, 2 vols., Zaragoza, Anubar.

Vidal Castro, Francisco (2000), Historia política, en Viguera Molins, María Jesús (coord.), El reino nazarí de Granada (1232-1492). Política, instituciones, espacio y economía, Madrid, Espasa Calpe, pp. 47-248 (Historia de España dirigida por Menéndez Pidal, vol. VIII-3).

Vidal Castro, Francisco (2004), El asesinato político en al-Andalus: la muerte violenta del emir en la dinastía nazarí ( $s$. XIV), en Fierro, Maribel (coord.), De muerte violenta. Política, religión y violencia en Al-Andalus, Madrid, CSIC, pp. 349-397.

Vidal Castro, Francisco (2008), La Alhambra, como espacio de violencia política en la dinastía nazarí, en La Alhambra: lugar de la memoria y el diálogo, Granada, Comares, pp. 201-220.

Viguera Molins, María Jesús (ed.) (1989), La mujer en Al-Andalus: reflejos históricos de su actividad y categorías sociales, Madrid, Universidad Autónoma - Sevilla, Editoriales Andaluzas Unidas.

Viguera Molins, María Jesús (2011), La violencia ejemplar: crónicas y poder, en Crueldad y compasión en la literatura árabe e islámica, Madrid, CSIC - Servicio de Publicaciones de la Universidad de Córdoba, pp. 81-107.

Ženka, Josef (2012), Politické a vojenské elity v Granadském emirátu (Las élites políticas y militares en el emirato de Granada), Praga, Faculty of Arts, Universidad Carolina (tesis doctoral).

Ženka, Josef (2014), The Great Ruling Family of the Fourteenth Century: Mușāhara in the Age of Ibn Al-Khaț̄̄ en Boloix Gallardo, Bárbara (ed.), Praising the 'Tongue of Religion'. Essays in Honor of the 700th Anniversary of Ibn al-Khațīb's Birth (1313-2013), Leiden Boston, Brill, pp. 306-339 (Medieval Encounters; 20/4-5).

Ziriklī, Jayr al-Dīn (1969), Al-A lām: Qāmūs tarāŷim li-ašhar al-rî̀āl wa-l-nisā min al- arab wa-l-mustašribīn wa-l-mustašriqīn, s.l., s.n., $10+3$ vols. 
Zomeño Rodríguez, Amalia (2000), Dote y matrimonio en al-Andalus y el Norte de África. Estudio de la jurisprudencia islámica, Madrid, CSIC.

Zomeño Rodríguez, Amalia (2006), Siete historias de mujeres. Sobre la transmisión de la propiedad en la Granada nazarí, en Mujeres y sociedad islámica: una visión plural, Málaga, Universidad de Málaga.

Fecha de recepción del artículo: mayo 2015

Fecha de aceptación y versión final: febrero 2016 